\title{
Selection of Melon Genotypes with Resistance to Fusarium Wilt and Monosporascus Root Rot for Rootstocks
}

\author{
Dong Kum Park ${ }^{1}$, Seon-Hye Son ${ }^{1}$, Su Kim ${ }^{1}$, Woo Moon Lee ${ }^{1}$, Hee Ju Lee ${ }^{1}$, Hak Soon Choi ${ }^{1}$, Eun Young Yang ${ }^{1}$, \\ Won Byoung Chae ${ }^{1}$, Ho-Cheol Ko ${ }^{2}$, Yun-Chan Huh ${ }^{1} *$ \\ ${ }^{1}$ National Institute of Horticultural \& Herbal Science, RDA, Suwon 440-706, Republic of Korea \\ ${ }^{2}$ National Academy of Agricultural Science, RDA, Suwon 441-100, Republic of Korea
}

\begin{abstract}
A panel of 65 melon germplasm was used to screen for resistance to Fusarium oxysporum f. sp. melonis (Fom) and Monosporascus cannonballus. The screening test revealed 35 accessions that are highly resistant to Fom race 1 and 11 accessions with high resistance to M. cannonballus. A total of four accessions, 'K134068', 'K133069', 'Wondae' and 'PI 414723', showing resistance to both pathogens were selected as candidates for melon rootstock. Yield and quality of fruits harvested from 'Earl's elite' (Muskmelon, Reticulatus Group) grafted onto the selected melon rootstocks were found comparable to or better than those of non-grafted melons. Nearly negligible incidence of fruit fermentation was observed when 'Homerunstar' (Honeydew type, Inodorus Group) was grafted with the selected melon rootstocks, unlike when it was grafted onto 'Shintozwa' (Cucurbita spp.) rootstock. The selected melon accessions with resistance to Fusarium wilt and Monosporascus root rot are considered to be potential and valuable genetic resources for breeding program of melon.
\end{abstract}

Keywords Melon rootstock, Grafting, Soil-borne diseases, Monosporascus Root Rot, Fusarium wilt

\section{INTRODUCTION}

Soil-borne diseases aggravated by continuous cropping caused severe yield loss in melon production in Korea. Fusarium oxysporum f. sp. melonis (Fom) is believed to be the most destructive disease of melon (Lee 1994; Oda 1995). Fom attacks melon at any growth stage, even before sprouting, but mainly when the fruit is ripe (Mas et al. 1981). It causes either slow wilting accompanied by progressive yellowing, or a sudden wilting without prior yellowing and other related symptoms. Based on the host resistance genes associated with variants of this pathogen, Fom isolates were classified into four physiological races designated 0, 1, 2, and 1,2 (Risser et al. 1976).

Monosporascus cannonballus is another pathogen of melon which induces sudden wilting and has become a major production problem worldwide (Martyn and Miller 1996). Root infection and damage occur at all developmental stages but increase in water demand especially during fruit development and maturation can lead to vine collapse due to loss of water-uptake capacity (Martyn and Miller 1996).

Breeding new cultivars for disease resistance is timeconsuming and does not guarantee durable resistance against new races of pathogens. However, grafting onto resistant rootstocks may enable the control of soil-borne diseases (Lee 1994; Oda 1995). Hence, combined breeding programs could be applied to prevent the occurrence of soil-borne diseases (McCreight et al. 1993).

Grafting is an important technique for sustainable production of fruit-bearing vegetables in Korea, Japan, and European countries where land is being used intensively (Lee 1994; Oda 1995). Grafting in melon cultivation makes possible increase in disease resistance and tolerance to environmental stresses such as soil salinity and low temperature. The use of rootstocks also increases adaptability of melon cultivars against different type of soil conditions

Received September 12, 2013; Revised September 23, 2013; Accepted September 24, 2013; Published September 30,2013

*Corresponding author Yun-Chan Huh, wmelon@korea.kr, Tel: +82-31-240-3632, Fax: +82-31-240-3669 
including resistance to soil-borne diseases, which in turn contributes to total production yield and water use efficiency (Caruso et al. 1996; Yano et al. 2002). The available rootstock species for melon grafting are melon, pumpkin (Cucurbita spp.) and wax gourd (Benincasa hispida) (Traka-Mavrona et al. 2000). It was reported that the Cucurbita rootstock can influence performance of scion cultivars of melon in terms of plant growth (Ruiz and Romero 1999), fruit quality, yield, and wilt incidence (Ruiz et al. 1997; Traka-Mavrona et al. 2000; Nisini et al. 2002). Effects of grafting to the performance of plants depend on the compatibility between rootstocks and scions, existing environmental condition, and cultivation. This is the reason why Lee (1994) suggested Cucumis melo is suitable rootstock for melon.

The objectives of this study were to select melon rootstocks for resistance against $F$. oxysporum $\mathrm{f}$. sp. melonis (Fom) and M. cannonballus, and investigate the compatibility of the rootstock and scion being used.

\section{MATERIALS AND METHODS}

\section{Experiment location and plant materials}

The experiment was conducted at the National Institute of Horticultural \& Herbal Science in Suwon, Korea $\left(37^{\circ} 18^{\prime} 23^{\prime \prime} \mathrm{N}, 126^{\circ} 58^{\prime} 40^{\prime \prime} \mathrm{E}\right)$. A total of 65 melon accessions (Table 1) were screened for resistance against $F$. oxysporum f. sp. melonis race 1 and $M$. cannonballus.

\section{Screening against $F$. oxysporum f. sp. melonis race 1 and M. cannonballus}

Fom race 1 was isolated from infected melon plants grown in Suwon, Korea and grown on potato dextrose agar (Difco) in plastic petri-dishes at $25^{\circ} \mathrm{C}$ for eight days. Colonies were scraped off using sterilized glass rod from the petri dish added with $5 \mathrm{ml}$ sterile distilled water. The suspension was filtered through two layers of sterile cheesecloth and the conidia were adjusted to $1 \times 10^{6} \mathrm{~mL}^{-1}$ using hemacytometer. The roots of the 20-day-old plants were dipped into inoculum suspension for one minute and later transplanted into pots. Disease ratings were recorded three weeks after inoculation.

Screening of melon genotypes for resistance to $M$. cannonballus was conducted under infested greenhouse. Melon plants were transplanted on July 9, 2011 in a randomized complete block design with three replications per genotype. Each bed was of $190 \mathrm{~cm}$ in size containing rows which were set at $45 \mathrm{~cm}$ apart.

\section{Rootstock and scion compatibility test}

Two melon cultivars, 'Homerunstar' and 'Earl's elite', were grafted onto selected rootstocks: 'K134068', 'K133069', 'Wondae', and 'PI 414723', 'Shintozwa' (Cucurbita spp.). Both the rootstocks and scions were sown at the same time on March 31, 2011 for a synchronized grafting time. Grafting was done on April 8, 2011 when the melon seedlings (eight-day-old) are at cotyledon stage using the splice grafting technique described in Lee et al. (2010). The grafted seedlings were transferred into a mist room maintained at relative humidity of $95 \%$ for seven days. Humidity was gradually decreased later for acclimatization one week before transplanting.

Melon seedlings were transplanted in a greenhouse in rows with black polyethylene mulching films on May 7 , 2011. The experimental design was consisted of randomized blocks with three replicates. A total of seven plants per replication was grown horizontally and spaced at $3 \times 0.5 \mathrm{~m}$ (row-row x plant-plant) for each rootstock combination and cultivar. The cultivation was practiced as method described in Rural Developmental Administration (2005). Fruits from 'Homerunstar' and 'Earl's elite' were harvested 45 and 55 days after fruit setting, respectively. The weight, length, width, soluble solid content, net formation, fermentation and appearance rate of fruits were investigated after harvest.

\section{Statistical analyses}

The statistical analysis was done using SAS software (SAS Institute 1995). The data from all the experiments were subjected to ANOVA and Duncan's multiple range tests to determine the statistical significance of differences between treatments. 


\section{RESULTS AND DISCUSSION}

Of the 65 melon accessions screened to develop disease resistant rootstocks, 35 were found highly resistant (HR) to
Fom race 1 and 11 accessions showed high resistance to $M$. cannonballus (Table 1). Accessions with high resistance to both pathogens were selected as potential rootstocks for grafting, which include 'K134068', 'K133069', 'Wondae'

Table 1. Disease severity of melon genotypes against Fom race 1 and M. cannonballus.

\begin{tabular}{|c|c|c|c|c|c|}
\hline \multirow{2}{*}{ Accession } & \multicolumn{2}{|c|}{ Disease severity $^{z}$} & \multirow{2}{*}{ Accession } & \multicolumn{2}{|c|}{ Disease severity } \\
\hline & Fom race 1 & M. cannonballus & & Fom race 1 & M. cannonballus \\
\hline K134068 & HR & HR & Seolnaehyang & HR & $\mathrm{S}$ \\
\hline K134069 & HR & HR & $V-3-6$ & HR & S \\
\hline Wondae & HR & HR & Earlsace & MR & MR \\
\hline PI 414723 & HR & HR & Acur & $\mathrm{S}$ & HR \\
\hline Irannetmelon & HR & MR & Busan no.914 & $\mathrm{S}$ & HR \\
\hline Dalaman & HR & MR & Busan no.920 & $\mathrm{S}$ & HR \\
\hline Hwangkeumchamoe & HR & MR & Unknown 3 & S & HR \\
\hline Romans & HR & MR & Unknown 4 & S & HR \\
\hline Sageumok & HR & MR & Unknown 5 & S & HR \\
\hline Unknown 1 & HR & MR & Unknown 6 & $\mathrm{~S}$ & HR \\
\hline Unknown 2 & HR & MR & PMR Honeydew & S & SR \\
\hline B1 & HR & SR & Unknown 7 & S & SR \\
\hline Baekdangkwan & HR & SR & $05 \mathrm{M} 40$ & S & S \\
\hline Seonghwanchamoe & HR & SR & Charentais Fom 1 & $\mathrm{~S}$ & $\mathrm{~S}$ \\
\hline Cheongpisokwa & HR & SR & Chunhyang & S & S \\
\hline Chogambaekok & HR & SR & Unknown 8 & S & $\mathrm{S}$ \\
\hline Daryang no.1 & HR & SR & $05 \mathrm{M} 15$ & S & - \\
\hline Julchamoe & HR & SR & $05 \mathrm{M} 28$ & S & - \\
\hline Seonghwanchamoe & HR & SR & Acur Badem & $\mathrm{S}$ & - \\
\hline 05M41 & $\mathrm{HR}$ & S & Busan no.912 & $\mathrm{S}$ & - \\
\hline 05M42 & HR & S & Busan no.928 & S & - \\
\hline Charentais Fom 2 & HR & $\mathrm{S}$ & Busan no.951 & S & - \\
\hline Eunchoen & HR & S & Earlshappy & S & - \\
\hline Gam & HR & $\mathrm{S}$ & Gamkwanilho & $\mathrm{S}$ & - \\
\hline Gamro & HR & S & Giallo Canaria & $\mathrm{S}$ & - \\
\hline Geumnodagieuncheon & HR & S & Iranmelon & $\mathrm{S}$ & - \\
\hline Hong & HR & $\mathrm{S}$ & Papais & $\mathrm{S}$ & - \\
\hline Icheon & HR & $\mathrm{S}$ & Superstar & $\mathrm{S}$ & - \\
\hline Joseonchamoe & HR & S & Unknown 9 & S & - \\
\hline Korea no.18 & HR & S & Unknown 10 & $\mathrm{~S}$ & - \\
\hline Korea no. 2 & HR & S & Veedrantais & S & - \\
\hline New melon & HR & MR & West & $\mathrm{S}$ & - \\
\hline Oknaehyang & HR & $\mathrm{S}$ & Homrunstar & $\mathrm{S}$ & $\mathrm{S}$ \\
\hline
\end{tabular}

${ }^{7}$ Disease severity : $\mathrm{HR}=$ highly resistant, $\mathrm{MR}=$ moderately resistant, $\mathrm{SR}=$ slightly resistant, $\mathrm{S}=$ susceptible 
and 'PI 414723' (Table 1).

Assessment of the yield and quality of fruits harvested from 'Earl's elite' (Muskmelon, Reticulatus Group) and 'Homerunstar' (Honeydew type, Inodorus Group) grafted onto selected melon rootstocks was conducted. 'Homerunstar' and 'Earl's elite' are the most popular cultivars being harvested between July and August in Korea. The former is a honeydew type melon with creamy-white color and oblong shape, while the latter is a muskmelon with round shape. Performance of 'Earl's elite' grafted onto selected melon rootstocks was comparable to or even better than that grafted onto 'Shintozwa' and non-grafted melon (Table 2). There were no significant differences in both soluble solid content and net formation among 'Earl's elite' fruits from different rootstocks (Table 2). In particular, the 'Earl's elite' and 'K134069' combination outperformed the others in terms of fruit weight and fruit length (Table 2).

'Homerunstar' grafted onto selected four accessions also performed well or even better than that grafted onto 'Shintozwa' and non-grafted (Table 3). Combinations with
'K134068' and 'P1414723' edged out 'Shintozwa' rootstock and non-grafted in terms of fruit weight, fruit width, and appearance rate. No significant differences in fruit length and soluble solid content were observed among 'Homerunstar' fruits from different rootstocks (Table 3). Interestingly, the four rootstock-scion combinations had negligible fermented fruit incidence (0-6\%) which is similar to the non-grafted check (6\%) but way lesser than with 'Shintozwa' rootstock (81\%, Table 3).

Several conflicting reports regarding the role of grafting on changes in fruit quality have been published (Proietti et al. 2008; Flores et al. 2010). Reasons for differences in the previous reports might be attributed to different production environments and type of agricultural practice, kind of rootstock/scion combinations, and harvesting period. Previous reports also showed that Cucurbita spp. rootstock causes a remarkable deterioration in the taste of melons (Lee 1994; Oda 1995) even when the same cultural treatments such as fertilizer application and irrigation were practiced. The four rootstock accessions selected for disease resistance in

Table 2. Fruit quality of 'Earl's elite' (Muskmelon, Reticulatus Group) grafted onto different rootstocks.

\begin{tabular}{cccccc}
\hline \hline Rootstock & $\begin{array}{c}\text { Fruit weight } \\
(\mathrm{kg})\end{array}$ & $\begin{array}{c}\text { Fruit length } \\
(\mathrm{mm})\end{array}$ & $\begin{array}{c}\text { Fruit width } \\
(\mathrm{mm})\end{array}$ & $\begin{array}{c}\text { Soluble solid } \\
\text { content }\left({ }^{\circ} \mathrm{Bx}\right)\end{array}$ & $\begin{array}{c}\text { Net } \\
\text { formation }^{\mathrm{z}}\end{array}$ \\
\hline K134068 & $1.4 \mathrm{ab}$ & $151.4 \mathrm{ab}$ & $136.4 \mathrm{ab}$ & $14.6 \mathrm{a}$ & $3.1 \mathrm{a}$ \\
K134069 & $1.5 \mathrm{a}$ & $155.2 \mathrm{a}$ & $137.9 \mathrm{ab}$ & $13.8 \mathrm{a}$ & $3.5 \mathrm{a}$ \\
Wondae & $1.4 \mathrm{ab}$ & $151.4 \mathrm{ab}$ & $133.4 \mathrm{a}$ & $14.2 \mathrm{a}$ & $3.3 \mathrm{a}$ \\
PI 414723 & $1.3 \mathrm{ab}$ & $147.3 \mathrm{ac}$ & $131.7 \mathrm{ab}$ & $14.2 \mathrm{a}$ & $3.9 \mathrm{a}$ \\
Shintozwa & $1.2 \mathrm{~b}$ & $138.3 \mathrm{c}$ & $131.3 \mathrm{ab}$ & $14.8 \mathrm{a}$ & $3.5 \mathrm{a}$ \\
non-grafted & $1.2 \mathrm{~b}$ & $144.1 \mathrm{bc}$ & $129.3 \mathrm{~b}$ & $13.7 \mathrm{a}$ & $3.1 \mathrm{a}$ \\
\hline
\end{tabular}

${ }^{\mathrm{z}}$ Net formation : 1 good $\sim 9$ poor

Table 3. Fruit quality of 'Homerunstar' (honeydew type melon) grafted onto different rootstocks.

\begin{tabular}{ccccccc}
\hline \hline Rootstock & $\begin{array}{c}\text { Fruit weight } \\
(\mathrm{kg})\end{array}$ & $\begin{array}{c}\text { Fruit length } \\
(\mathrm{mm})\end{array}$ & $\begin{array}{c}\text { Fruit width } \\
(\mathrm{mm})\end{array}$ & $\begin{array}{c}\text { Soluble solid } \\
\text { content }\left({ }^{\circ} \mathrm{Bx}\right)\end{array}$ & $\begin{array}{c}\text { Fermented fruit } \\
(\%)\end{array}$ & $\begin{array}{c}\text { Appearance } \\
\text { rate }^{\mathrm{z}}\end{array}$ \\
\hline K134068 & $1.5 \mathrm{a}$ & $158.5 \mathrm{a}$ & $134.8 \mathrm{a}$ & $16.0 \mathrm{a}$ & 6 & $4.3 \mathrm{a}$ \\
K134069 & $1.4 \mathrm{ab}$ & $155.7 \mathrm{a}$ & $133.6 \mathrm{a}$ & $16.0 \mathrm{a}$ & 6 & $3.9 \mathrm{ac}$ \\
Wondae & $1.4 \mathrm{ab}$ & $155.6 \mathrm{a}$ & $130.1 \mathrm{ab}$ & $15.7 \mathrm{a}$ & 0 & $3.8 \mathrm{ac}$ \\
PI 414723 & $1.5 \mathrm{a}$ & $160.3 \mathrm{a}$ & $135.1 \mathrm{a}$ & $15.8 \mathrm{a}$ & 0 & $4.2 \mathrm{ab}$ \\
Shintozwa & $1.3 \mathrm{~b}$ & $150.8 \mathrm{a}$ & $126.8 \mathrm{~b}$ & $16.2 \mathrm{a}$ & 81 & $3.5 \mathrm{c}$ \\
non-grafted & $1.3 \mathrm{~b}$ & $153.1 \mathrm{a}$ & $126.4 \mathrm{~b}$ & $15.9 \mathrm{a}$ & 6 & $3.6 \mathrm{bc}$ \\
\hline
\end{tabular}

${ }^{\mathrm{z}}$ Appearance rate : 1 poor $\sim 5$ good 
the present study did not cause deterioration in fruit quality while a conventional rootstock 'Shintozwa' did cause remarkable deterioration (Table 3). It was then suggested that the agents associated with fruit quality were translocated to the scion through the xylem which is likely not the case here considering the fruit quality of the rootstock-scion combination.

\section{CONCLUSION}

This study was conducted to select melon rootstocks with resistance against Fusarium oxysporum f. sp. melonis (Fom) and Monosporascus cannonballus, and to investigate the compatibility of the rootstock and the scion being used. The initial screening of 65 genotypes led to selection of four accessions ('K134068', 'K133069', 'Wondae' and 'PI 414723') with high resistance to both Fom race 1 and M. cannonballus for use as rootstocks. Subsequent compatibility assessment of grafted plants with the selected four rootstocks revealed comparable or even better performance of these plants compared to the checks 'Shintozwa' and non-grafted ones in terms of yield, fruit quality and fruit fermentation incidence. The findings further disproved the previous report that rootstock caused a remarkable deterioration in the fruit quality.

The selected melon genotypes with resistance to Fusarium wilt and Monosporascus root rot would serve as potential and valuable genetic resource for improvement of melon. These genotypes could also be utilized in the breeding programs that target to combine with other desirable characteristics such as cold and salt tolerance among others to address the needs of new hybrid varieties that can be produced successfully under greenhouse conditions.

\section{ACKNOWLEDGMENT}

This work was supported with a grant from the National Institute of Horticultural and Herbal Science (Project No. PJ008638), Rural Development Administration, Republic of Korea.

\section{REFERENCES}

Caruso T, Giovannini D, Liverani A. 1996. Rootstock influences the fruit mineral, sugar and organic acid content of a very early ripening peach cultivar. J. Hort. Sci. 71: 931-937.

Flores FB, Sanchez-Bel P, Estan MT, Martinez-Rodrigues MM, Moyano E, Morales B, Campos JF, GarciaAbella JO, Egea MI, Fernandez-Garcia N, Romojaro F, Bolarin MC. 2010. The effectiveness of grafting to improve tomato fruit quality. Scientia. Hortic. 125: 211-217.

Lee JM. 1994. Cultivation of grafted vegetables, 1. Current status, grafting methods, and benefits. HortScience 29(4): 235-239.

Lee JM, Kubota C, Tsao SJ, Bie Z, Hoyos EP, Oda M. 2010. Current status of vegetable grafting: Diffusion, grafting techniques, automation. Scientia. Hortic. 127: 93-105.

Martyn RD, Miller ME. 1996. Monosporascus root rot/ vine decline: An emerging disease of melon worldwide. Plant Dis. 80:716-725.

Mas P, Molot PM, Risser G. 1981. Fusarium wilt of muskmelon. In: Fusarium Disease, Biology and Taxonomy, (P.E. Nelson, T.A. Toussoun, R.J. Cook, ed.), Pennsylvania State University Press, University Park, PA,USA. pp.169-177.

McCreight JD, Nerson H, Grumet R. 1993. Melon (Cucumis melo L.). In: Genetic Improvement of Vegetable Crops (Kallo G, Bergh BO, eds). Pergamon Press Ltd. pp.267-283.

Nisini PT, Colla G, Granati E, Temperini O. Crino P, Saccardo F. 2002. Rootstock resistance to fusarium wilt and effect on fruit yield and quality of two muskmelon cultivars. Scieintia Hortic. 93: 281-288.

Oda M. 1995. New grafting methods for fruit-bearing vegetables in Japan. Jarq 29: 187-194,

Proietti S, Rouphael Y, Colla G, Cardarelli M, De Agazio M, Zacchini M, Moscatello S, Battistelli A. 2008. Fruit quality of mini-watermelon as affected by grafting and irrigation regimes. J. Sci. Food. Agric. 88: 1107-114.

Risser G, Banihashimi Z, Davis DW. 1976. A proposed nomenclature of Fusarium oxysporum f. sp. melonis 
races and resistance genes in Cucumis melo. Phytopathology 66: 1105-1106.

Ruiz JM, Belakbir A, Lopez-Cantarero I, Romero L. 1997. Leaf-macronutrient content and yield in grafted melon plants, a model to evaluate the influence of rootstock genotype. Scientia Hortic.71: 27-234.

Ruiz JM, Romero I. 1999. Nitrogen efficiency and metabolism in grafted melon plants. Scientia Hortic. 81: 113-123.

Rural Developmental Administration. 2005. A series of cultivation on melon. Rural Development Administration Suwon, Korea.

Traka-Mavrona E, Koutsika-Sotiriou M, Pritsa T. 2000. Response of squash (Cucurbita spp.) as rootstock for melon (Cucumis melo L.) Scientia Hortic. 83: 353-362. Yano T, Inouc H, Shimizu Y, Shinkai S, Ochi M. 2002. Effects of Prumus tomentos and P. persica rootstocks on yield, fruit quality, dry matter partitioning and trunk cross-sectional area of six peach cultivars. J. Jan. Soc. Hort. Sci. 71: 730-737. 